\title{
Hubungan Karakteristik Morfologi Tubuh dengan Bobot Badan Ayam Bangkok Jantan
}

\author{
(CORRELATION BETWEEN THE MORPHOLOGICAL CHARACTERISTICS \\ OF THE BODY WITH THE WEIGHT OF MALE BANGKOK CHICKEN)
}

\author{
Hastuti*, Junaedi, Arfandika Putra \\ Program Studi Peternakan, \\ Fakultas Pertanian Perikanan dan Peternakan, \\ Universitas Sembilanbelas November, Kolaka, \\ Jl. Pemuda No. 339, Kolaka, \\ Sulawesi Tenggara, Indonesia 93517 \\ Telp (0405) 2321132; Fax (0405) 2324028 \\ *email: hastutijalla@gmail.com \\ No. HP: 085255092481
}

\begin{abstract}
ABSTRAK
Penelitian ini bertujuan untuk mengetahui hubungan antar morfologi tubuh dengan bobot ayam Bangkok jantan, sebagai salahsatu bahan pertimbangan dalam menyeleksi dan menduga bobot badan ternak ayam Bangkok. Materi penelitian adalah Ayam Bangkok jantan sebanyak 30 ekor, umur 12 bulan. Penelitian ini menggunakan metode kuantitatif (pengukuran). pengambilan sampel ayam Bangkok dilaksanakan dengan purposive sampling. Variabel yang diamati yaitu panjang shank (PS), Lebar Dada (LeDa), Lingkar shank (LiSi), Panjang Dada (PaDa), Panjang tibia (TiBi), Tinggi pundak (TiPu), Lingkar tibia (TiPi), Panjang Punggung (PaBa), Lingkar Dada (LiDa), Bobot Badan. Penelitian ini menggunakan metode eksperimen dengan analisis data menggunakan analisis regresi - korelasi. Nilai korelasi yang sangat lemah menunjukkan hampir tidak adanya korelasi antara variabel yang diamati, dari hasil penelitian ini didapatkan ada 3 variabel yang menunjukkan korelasi sangat lemah yaitu, bobot badan dengan panjang shank $(0,20)$, panjang tibia $(0,08)$ dan panjang badan $(0,21)$. Korelasi yang rendah antara bobot badan dengan panjang shank, panjang tibia dan panjang badan mengindikasikan bahwa parameter tesebut tidak bisa menduga bobot badan pada ayam Bangkok jantan.
\end{abstract}

Kata kunci: ayam Bangkok, korelasi, morfologi tubuh

\begin{abstract}
The purpose of this research is to know the relationship between the morphology of the body with the weight of the Bangkok male chicken body as a consideration in selecting the bodyweight of the male Bangkok chicken cattle. The research material is a male Bangkok chicken of 30 tails, aged 12 months. This research uses quantitative methods (measurements). Bangkok chicken Sampling is carried out with purposive sampling; several body sizes then measured the selected samples. The observed parameters are shank length (SL), chest width (CW), shank circumference (SC), chest-length (CL), tibia length (TL), shoulder height (Trickery), tibia circumference (TiPi), back length (BL), chest circumference (CC), weight. The research methods used are experimental with data analysis using correlation analysis. The fragile correlation value indicates that there is almost no correlation between the variables observed; from the results of the study, three variables are showing a very weak correlation i.e., bodyweight with a long shank (0.20), tibia length (0.08) and body length (0.21). A low correlation between body weight and long shank length, tibia length, and body length indicates that the parameter is not usable for bodyweight selection in male Bangkok chicken.
\end{abstract}

Keywords: chicken Bangkok, correlation, body morphology 


\section{PENDAHULUAN}

Ayam Bangkok merupakan ayam introduksi dari Bangkok (Thailand). Meskipun ayam Bangkok bukan ayam asli Indonesia, tetapi kini telah menjadi salah satu jenis ayam lokal karena sudah lama berada di Indonesia dan dikawinkan dengan ayam lokal asli (ayam kampung). Keturunannya yang dikenal dengan nama ayam Bangkok turunan tidak lagi sebesar ayam Bangkok asli, namun masih memiliki kelincahan, ketahanan tubuh, dan ketangguhan seperti tetuanya. Ayam Bangkok adalah hasil persilangan antara ayam Melayu dengan ayam lokal di daerah Ayutthaya, Bangkok Utara, yang ternyata berhasil dikembangkan sebagai bibit unggul, baik sebagai ayam petelur dan pedaging maupun sebagai ayam aduan (Sitanggang et al., 2015). Ayam Bangkok mempunyai ciri diantaranya, postur tubuh tegap besar, tinggi mencapai 50-60 cm, jengger tidak bergerigi dan terbagi menjadi tiga baris, paha gepeng tapi kokoh dan kulit berwarna kemerah-merahan. Pada bagian jengger, terdapat persentase frekuensi jengger $100 \%$ untuk bentuk ayam kapri di Indonesia dan Thailand. Hal ini terjadi karena alel $\mathrm{P}$ kapri merupakan yang alel dominan (Nishida et al., 1982).

Sifat kuantitatif merupakan salah satu parameter yang penting dalam program pemuliaan ayam. Ukuran tubuh merupakan salahsatu sifat kuantitatif. Sifat kuantitatif penting dalam bidang peternakan. Berdasarkan penelitan sebelumnya, ukuran tubuh seperti panjang femur, panjang shank, lingkar shank, dan lingkar dada sangat berperan penting dalam menduga produktivitas bobot Ayam (Hummairah et al., 2015).

Berdasarkan latarbelakang tersebut, Penulis berinisiatif melakukan riset dengan judul "Hubungan antara Karakteristik Morfologi dengan Bobot Badan Ayam Bangkok Jantan". Penelitian ini bertujuan untuk mengetahui hubungan antar morfologi anggota tubuh dengan bobot ayam Bangkok jantan sebagai salahsatu bahan pertimbangan dalam menyeleksi dan menduga bobot badan ternak ayam Bangkok.

\section{METODE PENELITIAN}

\section{Materi Penelitian}

Materi penelitian yang digunakan yaitu ayam Bangkok pejantan berjumlah 30 ekor, umur 12 bulan. Penelitian ini menggunakan, meteran, kamera, timbangan digital, calculator, alat tutlis menulis serta lembar tabel untuk mengisi data hasil pengukuran.

\section{Sumber dan Jenis Pengumpulan Data}

Penelitian ini menggunakan metode kuantitatif/pengukuran. Lokasi penelitian dan penentuan sampel ayam Bangkok menggunakan purposive sampling. Pengambilan kriteria sampel penelitian ayam Bangkok jantan berdasarkan ciri-ciri tertentu yaitu jenis kelamin jantan dan sudah dewasa. Ayam Bangkok yang memenuhi kriteria penelitian diukur bagian-bagian tubuhnya (gambar 1) dan dilakukan penimbangan .

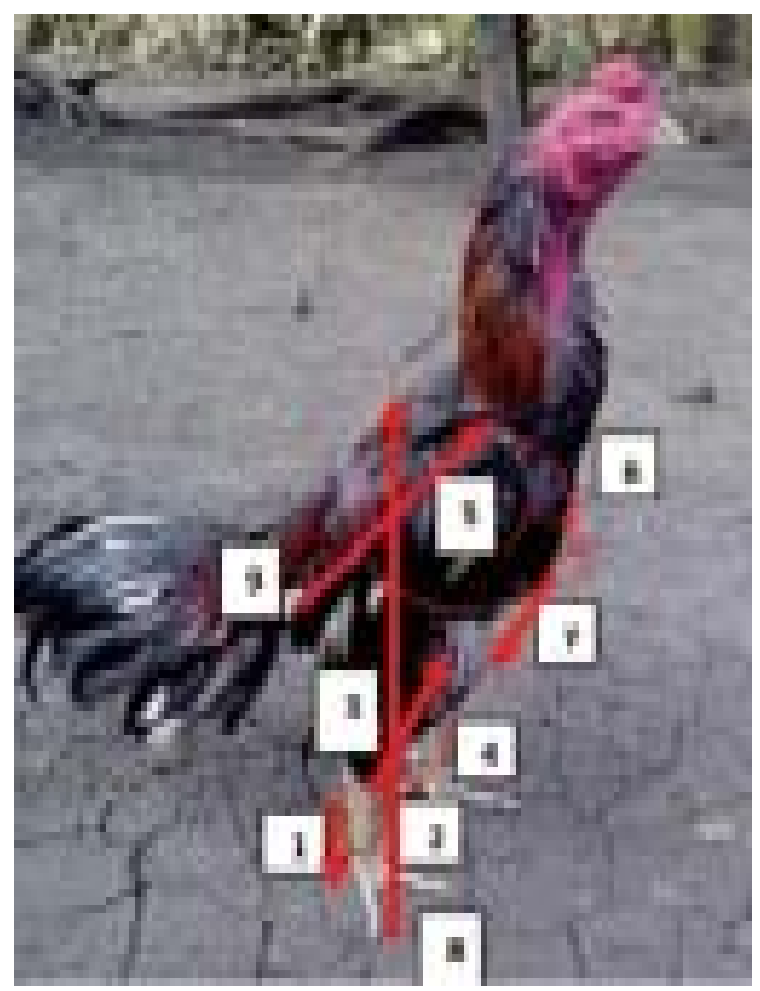

Gambar 1. Pengukuran Ukuran-ukuran tubuh ayam Bangkok jantan

Keterangan :

1. Panjang shank (PS); 2, Lingkar shank (LiSi);

3. Panjang tibia (TiBi); 4. Lingkar tibia (TiPi);

5. Lingkar Dada (LiDa); 6. Lebar Dada (LeDa);

7. Panjang Dada (PaDa); 8. Tinggi pundak (TiPu); 9. Panjang Punggung ( $\mathrm{PaBa})$

\section{Prosedur Penelitian}

Prosedur penelitian ini adalah melakukan penelitian pendahuluan sebagai bentuk acuan laporan untuk pra penelitian, memilih ternak 
ayam Bangkok sebanyak 30 ekor di Kabupaten Kolaka, melakukan pengukuran dimensi tubuh ternak dan melakuan penimbangan bobot badan, melakukan pencatatan atau recording, melakukan pengolahan data.

\section{Variabel Penelitian}

Variabel yang diukur pada riset ini meliputi morfologi tubuh ayam Bangkok jantan yang terdiri dari: (1) panjang shank (PS), (2) Lingkar shank (LiSi), (3) Panjang tibia (TiBi), (4) Lingkar tibia (TiPi), (5) Lingkar Dada (LiDa), (6) lebar dada (LeDa). (7) Panjang Dada (PaDa), (8) tinggi pundak (TiPu), (9) panjang punggung (PaBa), (10) Bobot Badan; dan Korelasi Bobot Badan dengan Ukuran Tubuh Ayam Bangkok Jantan.

\section{Analisis Data}

Jenis penelitian ini menggunakan metode eksperimental. Data dianalisis menggunakan analisis regresi-korelasi berdasarkan rumus Gomez dan Gomez (1996). Koefisien korelasi dihitung dengan menggunakan SPSS versi 25.

\section{HASIL DAN PEMBAHASAN}

\section{Morfologi Tubuh Ayam Bangkok Jantan}

Morfologi merupakan ilmu yang memelajari bentuk tubuh ternak. Tubuh ternak dibentuk oleh tulang dan otot. Jarak antar tulang atau antar persendian digunakan sebagai parameter pertumbuhan ternak. Parameter pertumbuhan ternak merupakan hasil pengukuran jarak antar tulang atau antar persendian yang disebut dengan ukuran-ukuran tubuh. Ukuran-ukuran tubuh merupakan faktor yang berkaitan erat dengan kinerja pertumbuhan ternak sehingga digunakan dalam performance test.

Sifat morfologi ini sangat mendukung berbagai korelasi ukuran tubuh dan pertumbuhan ayam. Recording morfologi tubuh ayam lokal (ayam bangkok) perlu dilakukan sebagai bahan informasi bagi orang yang berkecimpung bidang pemuliaan ternak ayam Bangkok. Program pemuliaan ternak tidak terlepas dari data kuantitatif suatu ternak. Data kuantitatif ternak digunakan untuk mengidentifikasi nilai ekonomis dan nilai performans suatu ternak. Sebagaimana yang dikemukakan oleh Sitanggang et al., (2015) bahwa untuk meningkatkan sumberdaya ayam lokal, perlu dilakukan langkah recording karakteristik morfologi ayam- ayam lokal yang bernilai ekonomis, seperti bobot badan dan ukuran tubuh.

Tabel 1. Nilai Rataan dan Simpangan Baku Ukuran Dimensi Tubuh Ayam Bangkok Jantan.

\begin{tabular}{lc}
\hline Dimensi Tubuh & $\begin{array}{c}\text { Rataan dan } \\
\text { Simpangan Baku }\end{array}$ \\
\hline Bobot badan $(\mathrm{kg})$ & $2,73 \pm 0,29$ \\
Tinggi pundak $(\mathrm{cm})$ & $38,00 \pm 2,10$ \\
Panjang badan $(\mathrm{cm})$ & $22,20 \pm 2,23$ \\
Panjang shank $(\mathrm{cm})$ & $12,17 \pm 0,59$ \\
Lingkar shank $(\mathrm{cm})$ & $6,50 \pm 0,86$ \\
Panjang tibia $(\mathrm{cm})$ & $14,00 \pm 1,78$ \\
Lingkar tibia $(\mathrm{cm})$ & $17,30 \pm 2,42$ \\
Lingkar dada $(\mathrm{cm})$ & $36,17 \pm 2,15$ \\
Lebar dada $(\mathrm{cm})$ & $12,43 \pm 2,69$ \\
Panjang dada $(\mathrm{cm})$ & $20,67 \pm 1,42$ \\
\hline
\end{tabular}

Berdasarkan hasil penelitian diperoleh beberapa sifat kuantitatif morfologi ayam Bangkok jantan yang diamati diantaranya adalah ukuran permukaan tubuh. Rataan ukuran permukaan tubuh dan simpangan baku meliputi: panjang shank, lingkar shank, panjang tibia, lingkar tibia, lingkar dada, lebar dada, panjang dada, tinggi pundak dan panjang badan. Karakteristik ukuran tubuh ternak ayam bangkok hasil penelitian bisa menjadi salahsatu dasar untuk mengetahui morfologi ayam Bangkok secara umum. Lebih lanjut Nishida et al. (1982) menjelaskan bahwa ukuran tubuh setiap ternak unggas yang meliputi . panjang shank, lingkar shank, panjang tibia, lingkar tibia, lingkar dada, lebar dada, dan panjang dada mencirikan jenis/ rumpun ternak yang dikelompokkan dalam satu rumpun yang sama.

Bobot Badan. Ayam Bangkok jantan memiliki rataan bobot badan yaitu $2,73 \pm 0,29$ $\mathrm{kg}$. Hasil penelitian pengukuran bobot badan lebih rendah dari hasil yang didapat oleh Rahmat (2003) yang mendapatkan hasil 3 - 4,5 kg. Perbedaan hasil penelitian disebabkan karena adanya perbedaan genetik, lingkungan tempat pengambilan data, mapun interaksi genetik dan lingkungan. Hal ini sesuai dengan pendapat Junaedi (2018) bahwa perbedaan lingkungan, parents, genetik, dan konsumsi pakan menjadi salahsatu faktor terjadinya keragaman pada ternak.

Rendahnya nilai bobot badan hasil penelitian menunjukkan produktivitas ternak 
berupa pembentukan otot sangat rendah. Salah satu yang sangat mempengaruhi adalah adanya temperatur lingkungan yang tinggi saat penelitian. Lebih lanjut Tamzil (2014) mengemukakan bahwa unggas tidak memiliki kelenjar keringat, dan hampir semua tubuh unggas ditutupi oleh bulu. Oleh karena itu, pembuangan panas tubuh ke lingkungan sulit, dan unggas cukup rentan terhadap stres panas. Demikian juga Aryania et al. (2019) melaporkan bahwa temperatur lingkungan yang tinggi memiliki dampak negatif pada kondisi fisiologis (aktivitas metabolisme dan hormonal, dan kontrol suhu tubuh) dan produktivitas ayam. Stres panas adalah masalah unggas utama di seluruh dunia, terutama pada ayam broiler dan petelur. Stres panas dapat terjadi kapan saja ketika suhu lingkungan melebihi batas zona nyaman $\left(>28^{\circ} \mathrm{C}\right)$. Stres panas pada ayam dapat menyebabkan gangguan pertumbuhan, penurunan kualitas telur, dan kematian.

Panjang Badan. Hasil penelitian menunjukkan rataan panjang badan ayam Bangkok jantan adalah 22,20 $\pm 2,23 \mathrm{~cm}$. Pada berberapa hasil penelitian melaporkan bahwa panjang tulang punggung ayam Bangkok sebesar 22,40 $\pm 2,16 \mathrm{~cm}$. Panjang badan pada ayam akan meningkat seiring dengan pertambahan umur, Semakin bertambahnya umur ayam, panjang badan juga meningkat. Panjang badan dikukur dari tulang ekor sampai tulang pundak. Panjang badan pada ayam berkaitan dengan panjang tulang punggung. Pertumbuhan panjang badan pada ayam Bangkok lebih cepat dibanding ayam lokal lainnya. Sehingga untuk meningkatkan performans ayam lokal, peternak biasanya menggunakan ayam Bangkok sebagai pejantan dalam persilangan ayam lokal.

Tinggi Pundak. Rataan tinggi pundak ayam Bangkok jantan adalah 38,00 $\pm 2,10 \mathrm{~cm}$. Pengukuran tinggi pundak ayam Bangkok dimulai dari tanah sampai pada tulang pundak ayam. Salahsatu ciri khas ayam Bangkok adalah tubuh tinggi dan berdiri tegak. Karakteristik tubuh tegak pada ayam Bangkok mempengaruhi penampakan yang tegak pada ayam Bangkok. Hal ini sesuai pendapat Permatasari et al., (2013) bahwa ukuran morfologi tubuh ternak unggas mencirikan suatu rumpun tertentu.

Tinggi pundak menggambarkan tingkat laju pertumbuhan pada ayam. Laju pertumbuhan pada ayam bisa diketahui dengan mengukur tinggi pundak. Pertumbuhan ayam bangkok yang cepat menjadi indikator kemampuan ayam Bangkok memproduksi hormon insulin. Hal ini sejalan dengan pendapat Daryono et al., (2010) bahwa hormon insulin menjadi indikator kemampuan tumbuh dan berkembang pada tubuh ayam.

Panjang Shank dan Lingkar Shank. Panjang shank ayam Bangkok jantan adalah $12,17 \pm 0,59 \mathrm{~cm}$. Hasil penelitian tersebut lebih tinggi dibanding hasil penelitian Sitanggang et al. (2015) 106,59A $\pm 10,853$ dengan kisaran rataan $10,15 \mathrm{~cm}$. Namun pada lingkar shank hasil penelitian pada ayam Bangkok jantan $6,50 \pm 0,86$ $\mathrm{cm}$. Hasil penelitian morfologi ayam Bangkok yang telah dilakukan lebih kecil dari riset yang dilakukan oleh Sitanggang et al. (2015) yang memperoleh nilai 68,80 $\pm 5,723$ dengan kisaran rataan $8,31 \mathrm{~cm}$. Ukuran panjang shank dan lingkar shank adalah bagian terpenting pada ayam dalam menopang tubuhnya sehingga dapat meningkatkan produktivitas ayam. Panjang shank dan panjang paha merupakan morfologi ayam yang berperan dalam produktivitas. Panjang shank dan lingkar shank yang besar menjadi salahsatu ciri khas yang dimiliki oleh ayam Bangkok, sehingga ayam Bangkok dikenal juga sebagai salahsatu tipe ayam aduan. Kemampuan bertarung ayam Bangkok didukung oleh bentuk morfologi yang kompak dan besar.

Panjang Tibia dan Lingkar Tibia. Ayam Bangkok jantan memiliki panjang tibia 14,00 $\pm 1,78 \mathrm{~cm}$ dan lingkar tibia yaitu $17,30 \pm 2,42 \mathrm{~cm}$. Panjang tibia pada ayam Bangkok hasil penelitian lebih rendah dari hasil yang diperoleh Sitanggang et al. (2015) dengan panjang tibia pada ayam Bangkok adalah 144,78A $\pm 10,154$ atau rataan 7,01. Adanya perbedaan ukuran tubuh ini selain dipengaruhi faktor genetik, juga dapat dipengaruhi faktor manajemen dan pemberian pakan. Hal ini sesuai pendapat Pagala et al., (2015) bahwa Faktor genetik dan lingkungan mempengaruhi keragaman hewan. Pendapat ini didukung oleh Putri (2010) bahwa performans sifat kuantitatif ukuran tubuh dipangaruhi oleh genetik, lingkungan dan interaksi keduanya. Secara genetik, bentuk tibia dan lingkar tibia pada ayam Bangkok memiliki ciri khas tersendiri dibanding ayam lokal lainnya. Pecinta ayam aduan biasanya menggunakan tibia sebagai penciri kemampuan beradu pada ayam Bangkok. Sisik tibia yang memiliki model tertentu dan bentuk yang unik menjadi penilaian tersindiri oleh pecinta ayam Bangkok. 
Lingkar Dada, Lebar Dada, dan Panjang Dada. Ukuran lingkar dada ayam Bangkok jantan adalah $36,17 \pm 2,15 \mathrm{~cm}$, lebar dada $12,43 \pm 2,69 \mathrm{~cm}$ dan panjang dada $20,67 \pm$ $1,42 \mathrm{~cm}$. Perbedaan ini disebabkan karena adanya perbedaan genetik. Lingkar, lebar, dan panjang dada pada ayam digunakan untuk menaksir berat daging pada ayam. Dada merupakan salahsatu bagian karkas ayam yang memiliki daging yang banyak. Dada yang besar pada ayam Bangkok bisa digunakan sebagai salahsatu bangsa ayam lokal sebagai penghasil daging. Program pemuliaan melalui proses presilangan dan seleksi ayam Bangkok bisa mempercepat peningkatan produktivitas ayam Bangkok sebagai ayam pedaging.

\section{Korelasi Bobot Badan dengan Ukuran Tubuh Ayam Bangkok Jantan.}

Performa ayam bankok sangat dipengaruhi juga faktor gen dalam mengekspresikan ukuran-ukuran tubuh. Sebagaimna Jakaria et al. (2012) menyatakan bahwa keberadaan gen harus dibuat dan dapat digunakan sebagai penanda gen yang secara ekonomis sangat penting sebagai bentuk dukungan dalam sistem pembiakan modern. Program berkembangbiakan yang juga membantu seperti gen $\mathrm{Na}$ diperlukan untuk mendukung konservasi dalam upaya dan perbaikan utilitas pada ayam.

Berdasarkan hasil penelitian didapatkan tiga hasil korelasi bobot badan ayam Bangkok jantan dengan morfologi tubuh ayam Bangkok yaitu korelasi tinggi, rendah dan sangat rendah. Hasil perhitungan koefisien korelasi tercantum pada tabel 2.

Korelasi Tinggi. Koeûsien korelasi bobot badan ayam Bangkok dengan ukuran morfologi tubuh ayam Bangkok yang memiliki korelasi tinggi $(\mathrm{P}<0.01)$ pada penelitian ini yaitu korelasi bobot badan dengan lingkr tibia $(0,74)$, lingkar dada $(0,72)$, lebar dada $(0,78)$, dan panjang dada $(0,73)$. Menunjukkan bahwa hasil korelasi beberapa variabel diatas adalah korelasi positif atau menunjukkan korelasi kuat. Hal tersebut sesuai dengan kriteria (Sarwono, 2006) menunjukkan nilai Korelasi kuat yaitu $(0,50$ $0,75)$. Penelitian tersebut hampir sama dengan hasil Lbe dan Nwakalor (1986) pada risetnya mendapatkan nilai korelasi panjang badan dengan bobot badan 0,99 penggunaan sampel ayam Broiler selama dua belas minggu.

Korelasi bobot badan dengan bagian bagian dada pada ayam Bangkok tersebut menunjukkan korelasi sangat nyata. Sebagaimana yang dikemukakan oleh Supranto (1996) hubungan yang positif dan mendekati nilai satu memiliki korelasi sangat nyata. Hal ini juga sesuai dengan hasil penelitian Gizaw et al. (2008) yang melaporkan bahwasanya bobot badan dengan bagian tubuh pada dada berkorelasi tinggi.

Nilai korelasi yang tinggi antara bobot badan dengan lingkar dada, panjang dada dan lebar dada pada ayam Bangkok jantan hasil penelitian, bisa dijadikan sebagai parameter dalam seleksi dan pendugaan bobot badan. Nilai korelasi yang tinggi juga memiliki banyak kegunaan diantaranya untuk menaksir/ memprediksi prestasi suatu ternak. Hasil penelitian ini sejalan dengan pendapat Permatasari et al (2013) bahwa korelasi yang tinggi antara morfologi tubuh dengan bobot badan pada ayam bisa dijadikan sebagai parameter untuk menaksir bobot badan. Lebih lanjut pembuktian peran ayam bangkok jantan sebagaimana yang dilaporkan Lapihu et al. (2019) bahwa penggunaan pejantan Bangkok dalam persilangan dapat meningkatkan bobot badan sebagai efek heterosis. Sifat heterosis yang baik pada keturunan ayam Bangkok bisa berpeluang

Tabel 2. Koefisien korelasi antar dimensi tubuh ayam Bangkok jantan

Korelasi antar ukuran tubuh ayam Bangkok

Nilai korelasi

Keterangan

\begin{tabular}{lcc}
\hline Korelasi Bobot badan - panjang shank & 0,20 & sangat rendah \\
Korelasi Bobot badan - lingkar shank & 0,43 & rendah \\
Korelasi Bobot badan - panjang Tibia & 0,08 & sangat rendah \\
Korelasi Bobot badan - Lingkar Tibia & 0,74 & tinggi \\
Korelasi Bobot badan - Lingkar Dada & 0,72 & tinggi \\
Korelasi Bobot badan - Lebar Dada & 0,78 & tinggi \\
Korelasi Bobot badan - Panjang Dada & 0,73 & tinggi \\
Korelasi Bobot badan - Tinggi Pundak & 0,35 & tinggi \\
Korelasi Bobot badan - Panjang Badan & 0,21 & sangat rendah \\
\hline
\end{tabular}


untuk diwariskan dengan menyilangkan ayam Bangkok dengan bangsa ayam yang memiliki kekerabatan jauh. Hal ini sejalan dengan pendapat Zainal et al., (2021) bahwa sifat heterosis positif bisa didapatkan dengan menyilangkan ternak yang memiliki kekerabatan jauh. Begitupula pendapat Banjarnahor et al., (2014) bahwa ternak yang emiliki keragaman dekat kecil untuk menghasilkan sifat heterosis positif.

Korelasi Rendah. Sesuai dengan nilai standar korelasi rendah yaitu $>0,25-0,5$ (Sarwono, 2006), dari hasil penelitian ini didapatkan korelasi bobot badan dengan ukuran morfologi ayam Bangkok yang rendah yaitu bobot badan dengan lingkar shank $(0,43)$ dan bobot badan dengan tinggi pundak $(0,35)$. Nilai hasil penelitian ini menunjukkan korelasi positif tetapi nilai korelasinya lemah atau cukup. Panjang shank mempunyai korelasi yang positif dengan bobot badan.

Ukuran panjang shank dan lingkar dada penting dalam hubungannya dengan bobot badan. Korelasi antara morfologi tubuh dan bobot badan tidak lepas dari pengaruh nilai heritabilitas sifat keragaman genetik. Ayam Bangkok jantan pada berbagai persilangan sering digunakan sebagai indikator dalam meningkatkan performa keturunan yang dihasilkan. Sebagaimana Soeroso et al. (2009) menyatakan bahwa Keragaman genetik pada ternak menjadi peluang yang baik untuk meningkatkan mutu genetik.

Korelasi Sangat Rendah. Nilai korelasi yang sangat lemah menunjukkan hampir tidak adanya korelasi antara variabel yang diamati, dari hasil penelitian ini didapatkan ada 3 variabel yang menunjukkan korelasi sangat lemah yaitu, bobot badan dengan panjang shank $(0,20)$, panjang tibia $(0,08)$ dan panjang badan $(0,21)$. Korelasi yang rendah antara bobot badan dengan panjang shank, panjang tibia dan panjang badan mengindikasikan bahwa parameter tesebut tidak bisa digunakan untuk seleksi bobot badan pada ayam Bangkok. Lebih lanjut Sitanggang et al. (2015) menyatakan bahwa korelasi yang rendah pada ukuran tubuh tidak bisa dijadikan sebagai penduga bobot badan. Adanya perbedaan kerangka penyusun tubuh dipengaruhi oleh genetik dan lingkungan.

\section{SIMPULAN}

Korelasi antara bobot badan dengan morfologi ayam Bangkok jantan semuanya bernilai positif (berkorelasi). Nilai korelasi tinggi adalah bobot badan dengan lingkar tibia $(0,74)$, lingkar dada $(0,72)$, lebar dada $(0,78)$, dan panjang dada $(0,73)$. Nilai korelasi rendah adalah bobot badan dengan lingkar shank $(0,43)$ dan tinggi pundak $(0,35)$, sedangkan nilai korelasi sangat rendah adalah bobot badan dengan panjang shank $(0,20)$, panjang tibia $(0,08)$ dan panjang badan $(0,21)$.

\section{SARAN}

Sebagai bahan pertimbangan dalam menduga bobot badan ternak ayam Bangkok jantan, maka parameter yang bisa digunakan adalah lingkar tibia, lingkar dada, lebar dada, dan panjang dada.

\section{UCAPAN TERIMA KASIH}

Tim Penulis menyampaikan ucapan terima kasih kepada Pimpinan kampus Universitas Sembilanbelas November Kolaka yang telah memberikan dukungan dalam penelitian sehingga terwujudnya artikel jurnal ini, dan juga kepada kelompok petani peternak Suka Maju atas kerjasamanya selama proses penelitian berjalan.

\section{DAFTAR PUSTAKA}

Aryania A, Solihinb DD, Sumantric C, Afnanc R, Sartikad T. 2019. Genetic Diversity of the Structure of HSP70 Gene in Kampung Unggul Balitbangtan (KUB), Walik, and Kate Walik Chickens. Tropical Animal Science Journal 42(3):180-188. DOI: https://doi.org/10.5398/tasj.2019. 42.3.180. [20 Januari 2020]

Banjarnahor N., U. Budi, \& Hamdan. 2014. Estimasi jarak genetik dan faktor peubah pembeda bangsa babi (berkshire, duroc, landrace, dan yorkshire) melalui analisis morfometrik di BPTU babi dan kerbau siborong-borong. JPI 2(2):165-167. 
Daryono, B.S., I. Roosdianto, \& H.T.S. Saragih. 2010. Pewarisan karakter fenotip ayam hasil persilangan ayam pelung dengan ayam cemani. Jurnal Veteteriner 11(4): 257-273.

Gizaw S, Komen H, Arendonk JHM. 2008. Selection on linear size tries to improve live weight in Menz sheep under nucleus and village breeding programs. Livestock Sci. 118: 92-98.

Gomez KA, Gomez AA. 1996. Statistical Procedure for Agricultural Research. Institute of Rice Research. Los Banos.

Hummairah R, Hamdan, Daulay AH. 2015. Identifikasi morfometriks dan jarak genetik ayam Kampung (domesticated chicken) di Kabupaten Batubara. Jurnal Peternakan Integratif 3(3): 329-343.

Lbe SN, Nwakalor LN. 1986. Growth patterns and conformation in broilers: influence of genotype and management on isometry of growth. Poultry Science 66: 1247-11251.

Jakaria, Ulfah M, Putri DA. 2012. Phenotypic characteristics of legund chickens in West Java, Indonesia. Proceeding of the 2nd International Seminar on Animal Industry, Jakarta, 5-6 July 2012: 130-134. https:// www.researchgate.net/publication/ 303895324_Phenotypic_characteristics_of_ legund_chicken_in_West_Java_Indonesia. [15 Desember 2019]

Junaedi dan Khaeruddin 2018. Review the Productivity of Kampung Chicken with Bangkok Chicken on Extensive System Maintenance. Chalaza journal of animal husbandry 3 (1). URL: http://dx.doi.org/ 10.31327/chalaza.v3i1.462

Lapihu YL, Telupere FMS, Sutedjo H. 2019. Kajian fenotip dan genetik performa pertumbuhan dari persilangan ayam lokal dengan ayam ras petelur Isa Brown. Jurnal Sain Peternakan Indonesia 14(3): 298-305. https://doi.org/10.31186/jspi.id.14.3.298-305. [15 Januari 2020].

Nishida T, Hayashi Y, Nozawa K, Thashiguchi, Mansjoer SS. 1982. Body Measurement and analysis of external genetic character of Indonesian native fowl. The Origin and Philogeny of Indonesian Native Livesstock 3: 73-83.
Pagala, M.A., A.M. Tasse, \& N. Ulupi. 2015. Association of cGH EcoRV Gene with Production in Tolaki Chicken. IJSBAR 24(7): 88-95.

Permatasari TE, Kurnianto E, Purbowati. 2013. Hubungan antara ukuran - ukuran tubuh dengan bobot badan pada kambing Kacang di Kabupaten Grobogan, Jawa Tengah. Animal Agriculture Journal 2(1): 28-34.

Putri DA. 2010. Karakteristik Kualitatif dan Kuantitatif Ayam Leher Gundul (Legund) di Kabupaten Subang dan Bogor, Jawa Barat. Bogor. Fakultas Peternakan IPB. http://repository.ipb.ac.id/handle/ 123456789/62983?showefull.

Rahmat R. 2003. Intensifikasi dan Kiat Pengembangan Ayam Buras. Penerbit Kanisius. Yogyakarta.

Sarwono B. 2002. Beternak Kambing Unggul. Penebar Swadaya, Jakarta.

Sitanggang EN, Hasnudi, Hamdan. 2015. Keragaman sifat kualitatif dan morfometrik antara ayam Kampung, ayam Bangkok, ayam Katai, ayam Birma, ayam Bagon dan Magon di medan. Jurnal Peternakan Integratif 3(2): 167-189.

Soeroso, Duma Y, Mozin S. 2009. Nilai heritabilitas dan korelasi genetik sifat pertumbuhan dari silangan ayam lokal dengan ayam bangkok. J Agroland 16(1): 67-71.

Tamzil, MH. 2014. Stres panas pada unggas: metabolisme, akibat dan upaya penanggulangannya. Wartazoa 24: 57-66.

Zainal HT. Sartika D. Zainuddin, \& Komarudin. 2012. Persilangan pada Ayam Lokal (KUB, Sentul, Gaok) untuk Meningkatkan Produksi Daging Unggas Nasional. Workshop Nasional Unggas Lokal. Balai Penelitian Ternak. Bogor. 